\title{
Socioemotional wealth in gay-owned family businesses: A pitch
}

\author{
Ondřej Machek ${ }^{\mathrm{a}, 1}$ and Aleš Kubíček ${ }^{\mathrm{a}}$ \\ ${ }^{a}$ Faculty of Business Administration, University of Economics, Prague
}

\begin{abstract}
In Western countries, there is a growing number of children raised by same-sex couples. The meaning of the term "family" has been evolving over the past decades, as well as the meaning of "family business". Based on the Faff's (2015) pitching research template, we present a pitch related to the postmodern family businesses. The intersection of family business socioemotional wealth perspective and queer studies presents an exciting area of research. The main research question is "Do gay-owned family businesses follow the same set of goals as traditional family firms?" In this letter, we also present our reflections on how the pitching research template can be used to prepare a research project related to this topic.
\end{abstract}

Keywords: LGBT, family business, pitching research, pitching template.

JEL codes: M10, L22

\section{Introduction}

The development of a research idea is a non-trivial process. Faff $(2015 ; 2019)$ presented a systematic and straightforward approach to outlining a new empirical research proposal. The "pitching template" is a tool which allows for articulation of the critical idea, data and methodology and expected contribution of a research project. While it may serve as a tool for presenting research of junior researchers, it is also useful for organising more experienced researchers' ideas. However, the

${ }^{1}$ Corresponding authors: Faculty of Business Administration, University of Economics, Prague; nam. W. Churchilla 4, 13067 Prague, Czech Republic; tel. (+420) 224098625 , email address: ondrej.machek@vse.cz 
template may serve for various other purposes, such as research skills development (Faff et al., 2016a), or a research teaching tool (Faff, 2016b).

In this research letter, we present the reflections on the use of the pitching template when conceiving a research idea related to the intersection of two relatively new fields of research. Although no research devoted to our research question exists today, the pitch can be considered "real" as we intend to develop the idea further in a real research project.

Family businesses are generally considered to follow a set of family-centred noneconomic goals. Often, their characteristic behaviour is explained using the socioemotional wealth (SEW) approach (Gómez-Mejía et al., 2007). To develop the measurement of SEW, Berrone et al. (2012) defined five primary dimension of SEW: (1) family control and influence; (2) identification of family members with the firm; (3) binding social ties; (4) emotional attachment; and (5) renewal of family bonds to the firm through dynastic succession.

Some sources state that there are about 200,000 children raised by same-sex couples in the US (Gates, 2015). At the same time, due to the development of legislation in the West, gay-owned businesses are considered to be "family firms" in some countries (Clark, 2013). LGBT (lesbian, gay, bisexual, and transgender) firms are a relatively new research object, and what we know today is based only on studies with a limited number of participants. Data on gay-owned family firms are absent to date. Unlike traditional firms, gay business leaders often encounter various kinds of prejudice (Fasoli et al., 2017) or micro-aggressions (Haines et al., 2018); at the same time, there is evidence that same-sex parents perform equally well as their "traditional" peers (Knight et al., 2017), suggesting that the socioemotional approach might be adapted to the context of LGBT firms.

\section{Commentary on the Pitch}

We aim to investigate the following research question: "Do gay-owned family businesses follow the same set of goals as traditional family firms?" Table 1 displays the pitching template.

The three key papers are related to three areas. We include the paper of Berrone et al. (2012) as it presents the theoretical foundations for the individual socioemotional wealth components. Second, the paper of Fish et al. (2018) offers a review of queering methodologies and discusses them concerning traditional paradigms. Third, we include the paper of Knight et al. (2017) to justify the need and reasons for studying succession and longevity in LGBT firms, which is directly related to the existence of family-centred non-economic goals. 
Table 1: Completed 2-page pitch template on Socioemotional Wealth in Gay-Owned Family Businesses

\begin{tabular}{|c|c|c|c|c|c|}
\hline Pitcher's Name & $\begin{array}{l}\text { Ondřej Machek, } \\
\text { Aleš Kubíček }\end{array}$ & $\begin{array}{c}\text { FoR } \\
\text { category }\end{array}$ & $\begin{array}{c}\text { Family } \\
\text { business } \\
\text { Queer } \\
\text { studies }\end{array}$ & $\begin{array}{c}\text { Date } \\
\text { Completed }\end{array}$ & $06 / 06 / 2019$ \\
\hline (A) Working Title & \multicolumn{5}{|c|}{ Socioemotional Wealth in Gay-Owned Family Businesses } \\
\hline $\begin{array}{l}\text { (B) Basic } \\
\text { Research } \\
\text { Question }\end{array}$ & \multicolumn{5}{|c|}{$\begin{array}{l}\text { Do gay-owned family businesses follow the same set of goals as traditional } \\
\text { family firms? }\end{array}$} \\
\hline (C) Key paper(s) & \multicolumn{5}{|c|}{$\begin{array}{l}\text { Berrone, P., Cruz, C., \& Gomez-Mejia, L. R. (2012). Socioemotional wealth } \\
\text { in family firms: Theoretical dimensions, assessment approaches, and agenda } \\
\text { for future research. Family Business Review, 25(3), 258-279. } \\
\text { Fish, J. N., \& Russell, S. T. (2018). Queering methodologies to understand } \\
\text { queer families. Family Relations, 67(1), 12-25. } \\
\text { Knight, K. W., Stephenson, S., West, S., Delatycki, M. B., Jones, C. A., } \\
\text { Little, M. H., .. \& Wake, M. (2017). The kids are OK: It is discrimination, } \\
\text { not same-sex parents, that harms children. The Medical Journal of Australia, } \\
207(9), 374-375 .\end{array}$} \\
\hline $\begin{array}{l}\text { (D) } \\
\text { Motivation/Puzzle }\end{array}$ & \multicolumn{5}{|c|}{$\begin{array}{l}\text { Family firms are very heterogeneous. At the same time, the meaning of the } \\
\text { term "family" has been evolving over the past decades, and in some } \\
\text { countries, LGBT families have the same rights as traditional families. The } \\
\text { family business literature deals exclusively with traditional families. With } \\
\text { this research, we open a new direction of research focused on the } \\
\text { distinguishing features of gay-owned family businesses. In particular, we } \\
\text { explore if gay-owned family businesses follow the same set of goals as } \\
\text { traditional family businesses using the socioemotional wealth (SEW) } \\
\text { approach. }\end{array}$} \\
\hline THREE & \multicolumn{5}{|c|}{ Three core aspects of any empirical research project i.e. the "IDioTs" guide } \\
\hline (E) Idea? & \multicolumn{5}{|c|}{$\begin{array}{l}\text { The research is quantitative. Based on several papers from the queer studies } \\
\text { literature, we will hypothesise that the socioemotional wealth approach is } \\
\text { applicable in the case of gay-owned family businesses. However, we will } \\
\text { need to take into account the specifics of this class of firms. The extent to } \\
\text { which gay-owned family firms emphasise family-centred non-economic } \\
\text { goals will be tested. Regarding independent variables, the analysis will also } \\
\text { have to control for industry effects, firm size and maturation effects. }\end{array}$} \\
\hline (F) Data? & \multicolumn{5}{|c|}{$\begin{array}{l}\text { As there are no databases of gay-owned firms, we will need to contact the } \\
\text { LGBT chambers of commerce or other associations of gay-owned firms to } \\
\text { get potential respondents. The data will most likely be cross-sectional, } \\
\text { although it is possible to consider past performance or future growth } \\
\text { projections. As the gay-owned firms will be compared to family businesses, } \\
\text { we will also need to have data on family firms, which are better accessible. } \\
\text { Our research team already owns a database of Czech family businesses, } \\
\text { which is a result of past research projects. }\end{array}$} \\
\hline
\end{tabular}




\begin{tabular}{|c|c|c|c|c|c|}
\hline Pitcher's Name & $\begin{array}{l}\text { Ondřej Machek, } \\
\text { Aleš Kubíček }\end{array}$ & $\begin{array}{c}\text { FoR } \\
\text { category }\end{array}$ & $\begin{array}{c}\text { Family } \\
\text { business } \\
\text { Queer } \\
\text { studies }\end{array}$ & $\begin{array}{c}\text { Date } \\
\text { Completed }\end{array}$ & 06/06/2019 \\
\hline (G) Tools? & \multicolumn{5}{|c|}{$\begin{array}{l}\text { We will have to develop a survey based on the existing measurements of } \\
\text { socioemotional wealth published in the family business literature, for } \\
\text { instance, the items proposed by Berrone et al. (2012). These measures will, } \\
\text { however, need to be adapted to the context of gay-owned firms. Since the } \\
\text { research is quantitative and comparative in nature, we are likely going to use } \\
\text { linear or Tobit regression analysis, together with a Student's t-test to } \\
\text { compare group means. Standard assumptions of this kind of analysis will } \\
\text { have to be tested. }\end{array}$} \\
\hline TWO & \multicolumn{5}{|l|}{ Two key questions } \\
\hline (H) What's New? & \multicolumn{5}{|c|}{$\begin{array}{l}\text { As far as we know, there is no empirical study on gay-owned family } \\
\text { businesses in the current management literature. We found only one book } \\
\text { chapter mentioning the "queer family business" term. Moreover, generally, } \\
\text { the existing studies on gay-owned firms are based on a minimal number of } \\
\text { participants; generalised empirical findings are missing. }\end{array}$} \\
\hline (I) So What? & \multicolumn{5}{|c|}{$\begin{array}{l}\text { According to the National LGBT Chamber of Commerce, there were } 1.4 \\
\text { million LGBT business owners in the US in 2013. Even when abstracting } \\
\text { from possible human rights or freedom benefits, gay-owned firms } \\
\text { objectively possess a significant economic power. The results could suggest } \\
\text { actions for governments as well as LGBT business owners. }\end{array}$} \\
\hline ONE & \multicolumn{5}{|l|}{ One bottom line } \\
\hline (J) Contribution? & \multicolumn{5}{|c|}{$\begin{array}{l}\text { As there are no data on gay-owned family businesses at all, and we do not } \\
\text { know much about gay-owned firms in general, the main theoretical } \\
\text { contribution is opening a new direction of research. Due to the economic } \\
\text { power of LGBT-owned firms, the results may also have policy as well as } \\
\text { managerial implications. Understanding and supporting such firms may also } \\
\text { have societal outcomes in terms of the development of quality-of-life } \\
\text { indicators such as the Universal Human Rights index. }\end{array}$} \\
\hline $\begin{array}{l}\text { (K) Other } \\
\text { Considerations }\end{array}$ & \multicolumn{5}{|c|}{$\begin{array}{l}\text { There are ethical considerations regarding this topic, which may seem to be } \\
\text { controversial to some scholars or heteronormative cultures. } \\
\text { There are no data on gay-owned family businesses today, and hence, there is } \\
\text { a risk of accessibility to credible data. } \\
\text { The existence of prejudice may trigger sensitivity of survey questions and } \\
\text { lead to response bias. } \\
\text { Obsolescence risk is medium to high, since similar research may be carried } \\
\text { out by another research team. }\end{array}$} \\
\hline
\end{tabular}

Because of the nature of our research question, the research will be quantitative and focused on comparing traditional family businesses with gay-owned family businesses. The core theoretical approaches will be the socioemotional wealth theory, the theoretical foundations of queer studies and family studies. The above three theories allow us to outline the Mickey Mouse diagram characterising the novelty of our research idea (Fig. 1). The diagram is composed of three circles: 
"gay-owned firms" (as the core and underresearched concept), "socioemotional wealth" (traditional paradigm of the family business literature), and "family" (meaning the interpretation of the term, including raising children, succession issues and self-identification of an individual with the family). Our research question is located at the intersection of these three circles.

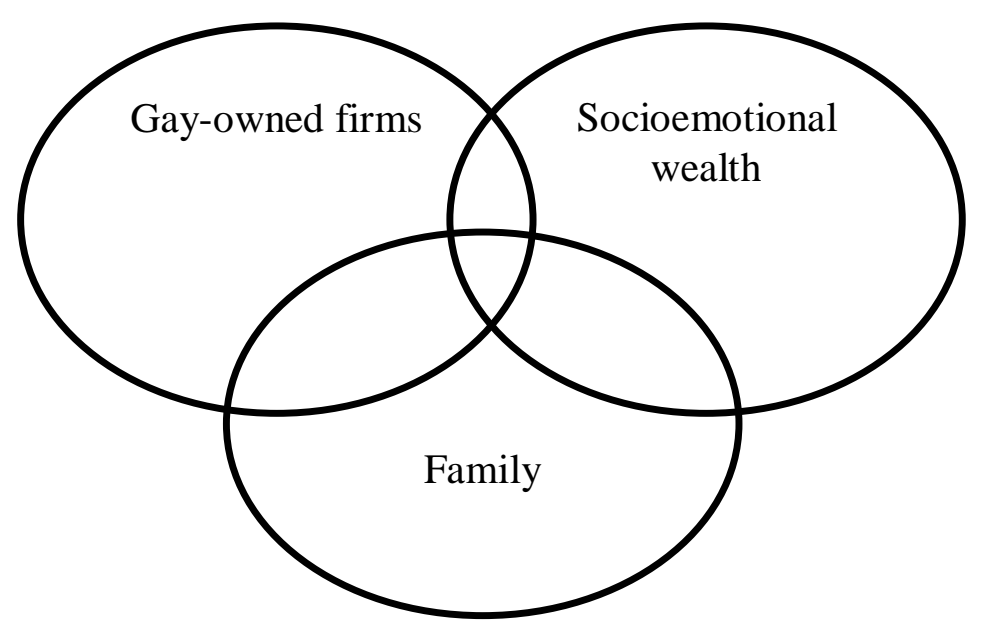

Figure 1. Mickey Mouse diagram characterising novelty of research idea

\section{Personal reflections on the pitching template application}

At our institution, the pitching template has been used by multiple researchers and PhD students (e.g., Dvouletý, 2017; Jurek, 2018; Machek, 2018). The use of the template originates in 2016 when prof. Faff held a lecture at the University of Economics, Prague. We completed a draft of the pitch in four days. Subsequently, we presented the pitch to our colleagues from the Center for Family Businesses at the Faculty of Business Administration and finalised the template in one week. The total time does not include the literature review, which has been done in advance. First, the preparation of the pitch allowed us to clarify the research question and the nature of the research. From a somewhat exploratory view, we proceeded to a relatively clear idea about what variables to test. However, as the pitching template is (and should be) brief, we do not elaborate in detail the specific constructs and variables which will enter into the model; these will be clarified at a later stage. Second, the pitch is very suitable for presenting a research idea to other researchers, or even to the public. We were able to present the initial pitch and then finalise it while keeping the research idea focused, yet ready for possible modifications based on the discussion with our colleagues. 


\section{Conclusion}

This letter aimed to develop and present a research idea using the pitching template of prof. Faff $(2015 ; 2019)$. We acknowledge that the use of the template may be very efficient for presenting and developing a research idea in a structured, systematic and brief way. We can only recommend the template to the prospective $\mathrm{PhD}$ students and novice researchers, but also more experienced authors when preparing real research projects. At the same time, we suggest reading the paper of Faff (2019) who explains and illustrates in detail other possible applications of the template.

\section{References}

Berrone, P., Cruz, C \& Gomez-Mejia, L.R. (2012) "Socioemotional wealth in family firms: Theoretical dimensions, assessment approaches, and agenda for future research", Family Business Review, vol. 25, no.3: 258-279

Clark, P. (2013) "Now a Gay-Owned Business Is a Family Business. Is More Government Work Next?", available at: https://www.bloomberg.com/news/articles/2013-06-27/now-a-gay-ownedbusiness-is-a-family-business-dot-is-more-government-work-next

Dvouletý, O. (2017) "Determinants of Nordic entrepreneurship: A reverse engineered pitch", Journal of Accounting and Management Information Systems, vol. 16, no.3: 420-426

Faff, R.W. (2015) "A simple template for pitching research", Accounting and Finance, vol. 55: 311-336

Faff, R.W., Godfrey, K. \& Teng, J. (2016a) "Pitching Research Evolution: An Illustrative Example on the Topic of Innovation and Financial Dependence", available at SSRN: http://ssrn.com/abstract=2776959

Faff, R.W., Li, Y., Nguyen, B.H. \& Ye, Q. (2016b) "Pitching Research: A Pilot Experiment with UQ Winter Scholars", available at SSRN: http://ssrn.com/abstract=2816233

Faff, R.W. (2019) "Pitching research", available at SSRN: http://dx.doi.org/10.2139/ssrn.2462059

Fasoli, F., Maass, A., Paladino, M.P. \& Sulpizio, S. (2017) "Gay-and lesbiansounding auditory cues elicit stereotyping and discrimination", Archives of Sexual Behavior, vol. 46, no.5: 1261-1277

Gates, G.J. (2015) "Marriage and family: LGBT individuals and same-sex couples", The Future of Children, vol. 25, no.2: 67-87

Gómez-Mejía, L.R., Haynes, K.T., Núñez-Nickel, M., Jacobson, K.J. \& MoyanoFuentes, J. (2007) "Socioemotional wealth and business risks in familycontrolled firms: Evidence from Spanish olive oil mills", Administrative Science Quarterly, vol. 52, no.1: pp. 106-137 
Haines, K.M., Boyer, C.R., Giovanazzi, C. \& Galupo, M.P. (2018) "Not a Real Family: Microaggressions Directed toward LGBTQ Families", Journal of Homosexuality, vol. 65, no.9: 1138-1151

Jurek, M. (2018) "Hybrid venture capital fundraising in emerging markets: A pitch", Accounting and Management Information Systems, vol. 17, no.1: $167-177$

Knight, K. W., Stephenson, S., West, S., Delatycki, M.B., Jones, C.A., Little, M.H., Patton, J.S., Sawyer, S.M., Skinner, S.R., Telfer, M.M., Wake, M., North, K.N. \& Oberklaid, F. (2017) "The kids are OK: It is discrimination, not same-sex parents, that harms children", The Medical Journal of Australia, vol. 207, no.9: 374-375

Machek, O. (2018) "Determinants of becoming a zombie firm: A pitch", Accounting and Management Information Systems, vol. 17, no.4: 677-684 